\title{
Controls on channel sinuosity changes: a case study of the Tisza River, the Great Hungarian Plain
}

\author{
Gábor Timár \\ Space Research Group, Department of Geophysics, Eötvös University of Budapest, Pázmány P. sétány 1/A, H-1117 Budapest, Hungary
}

Received 21 January 2002; accepted 15 November 2002

\begin{abstract}
The planform geometry of the Tisza, the trunk river of the subsiding Great Hungarian Plain is studied by reconstruction of the last pre-regulation river course. The thalweg sinuosity has been computed for the main alluvial section of the river. Remarkable sinuosity changes have been found to correlate with discharge and sediment load changes at the inflow of tributaries, as well as with active deformation areas, like differential subsidence and wrench fault zones.

Analysing the change of the river pattern, a new discrimination line has been derived, which separates the meandering zone on the classic slope vs. discharge diagram into two subzones. The first subzone (lower slope values) corresponds to a range of true, selforganized meandering. The second subzone (higher slope values) corresponds to a range of 'unorganized meandering'. This is a range where river sinuosity decreases although the channel slope increases. In the case of the Tisza River, this subzone equals to the wandering river pattern.
\end{abstract}

(C) 2003 Elsevier Science Ltd. All rights reserved.

\section{Introduction}

The Great Hungarian Plain (GHP), the central part of the Pannonian Basin, surrounded by the arc of the Carpathian Mts. (Fig. 1), is one of the world's most regularly developed floodplains. As a result of the stressinduced, thermal- and compaction-induced subsidence in the Quaternary (e.g. Horváth, 1993; Horváth and Cloetingh, 1996; Bada, 1999) the area is very flat; the relief undulations remain under $100 \mathrm{~m}$ on the GHP. This subsidence lasts up to now, although its rate shows differences in the area (Joó, 1992). In addition, the subsidence was equalized by river activity and fluvial sedimentation (Kázmér, 1990). The pre-Tertiary basement and the sedimentary fill of the GHP have been investigated by drilling campaigns (for a summary see Rónai, 1985) and seismic surveys (e.g. Lőrincz et al., 2002). The results show elongated SW-NE directed tectonic units in the basement rocks. One of the most important structures of the GHP is the MidHungarian Shear Zone (Pogácśas et al., 1989; Csontos et al., 1992), a sinistral strike-slip fault system whose

\footnotetext{
E-mail address: timar@1udens.elte.hu (G. Timár).
}

present activity was suggested by Bada et al. (1999) and Horváth and Bada (2001) using modelling of the stress field evolution of the Pannonian Basin. Using the data set presented by Mike (1975), Schumm et al. (2000) suggest that the westward shift of the Tisza River at the Late Pleistocene can be explained in terms of reactivation of the Mid-Hungarian Shear Zone and a change from an extensional to a compressive stress field.

An interesting question for the geology of the GHP is to what extent there are neotectonically active fault zones in the area. On industrial (e.g. hydrocarbon exploration) seismic sections the youngest reflectors are usually not imaged, therefore their use for neotectonic studies are very limited. Accordingly, interpretation of earthquake data, the riverine seismic surveys and the river planform analysis offer a good tool for neotectonic studies. As a result of the subsidence, in the historical times the GHP was mainly a large swamp, sparsely populated with only a few permanent buildings. Thus the small, or even the moderate earthquake events were not necessarily recorded (Tóth et al., 1995). The number of recorded earthquakes from the last 100 years is simply not enough for drawing a reliable conclusion. As 


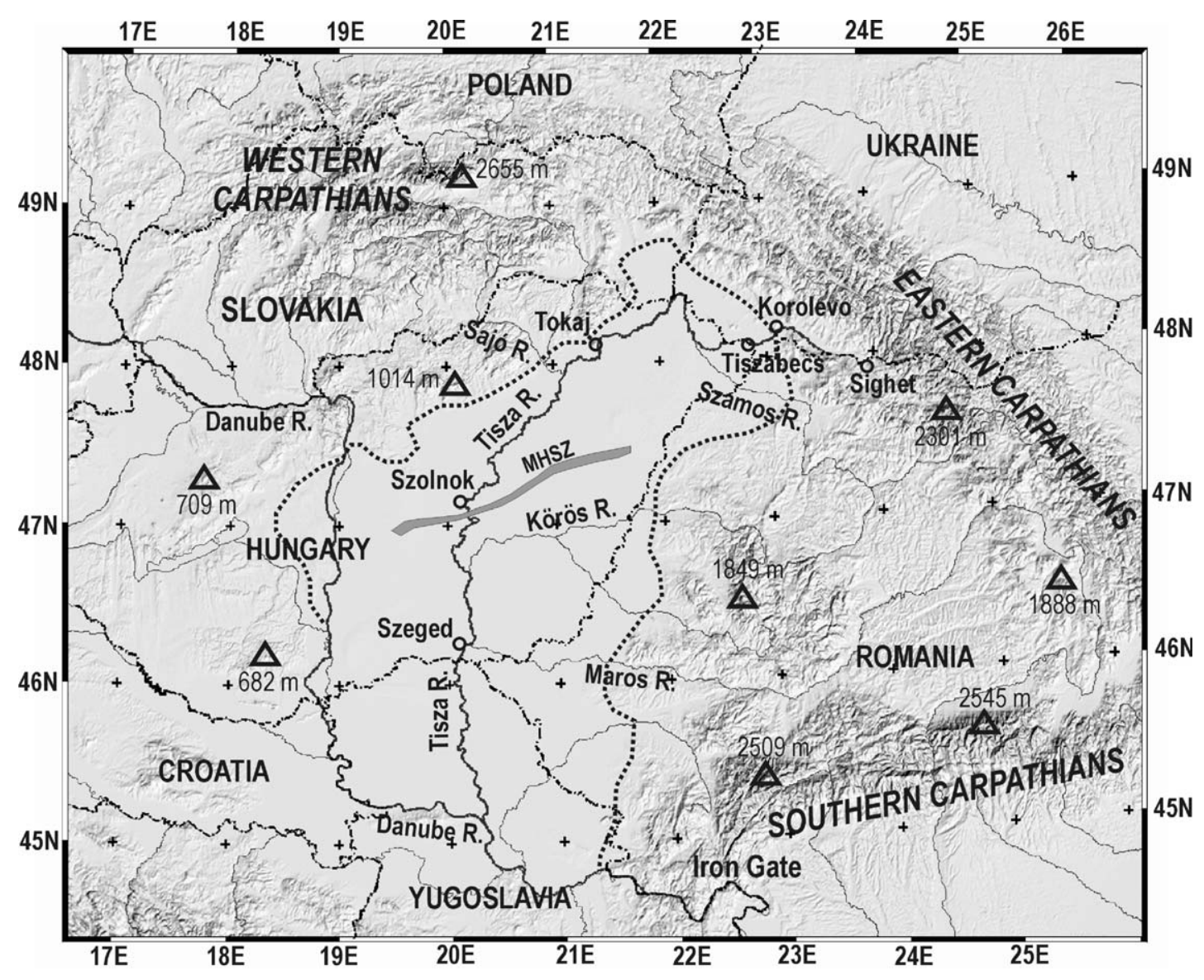

Fig. 1. Shaded relief map of the Pannonian Basin. Dash-dotted line indicates national frontiers, the boundary of the Great Hungarian Plain is shown by dotted line. MHSZ indicates the Mid Hungarian Shear Zone. The map is based on GTOPO30 global digital elevation data (GLOBE Task Team, 1999). The study section of the Tisza River is between the cities of Tokaj and Szeged.

presented in this paper, riverine seismic profiling and river planform analysis can be a useful tool to answer the questions of neotectonic activity and landform evolution.

The Tisza, the trunk river of the GHP, drains $157,000 \mathrm{~km}^{2}$, and its catchment area covers the eastern part of the Pannonian Basin. It originates in the Ukrainian part of the Carpathian Mts. and leaves its narrow valley at Sighet (on the Romanian-Ukrainian frontier) changing from a bedrock to an alluvial river. Its real braided section ends up at Korolevo where the river reaches the GHP (Fig. 1). From this point (the so called 'Korolevo Gate') till the estuary the Tisza is a river without any bedrock control.

The section from Korolevo to Tiszabecs represents the alluvial fan, therefore the main fraction of the river sediment is gravel and the river pattern is a transition from braided to meandering, which is called wandering type (Miall, 1977, 1996). The river starts the real meandering pattern at Tiszabecs and it lasts till the estuary, along the whole GHP.
On the plain the longitudinal profile of the river has only minor slope changes (Lászlóffy, 1982) and due to the flatness of the plain, the channel slope is less than $10 \mathrm{~cm} / \mathrm{km}$ everywhere downstream of Tokaj.

The annual mean discharge of the river at Szeged is about $800 \mathrm{~m}^{3} / \mathrm{s}$. Floods can occur in the spring season due to the snowmelt on the mountains of the catchment area. The Tisza flows to the Danube and the local erosional base of the whole Pannonian Basin is the Iron Gate where the Danube crosses the Southern Carpathian Mts. (Fig. 1).

The course of the river Tisza changed significantly during the late Quaternary (Gábris, 1998). The river pattern was alternating between braiding and meandering as a response to the climatic changes during the Pleistocene (Vandenberghe, 1995; Gábris, 1998). During the Holocene period the meandering pattern has been dominant everywhere downstream of the alluvial fan section of the Tisza River (Gábris, 1987). 

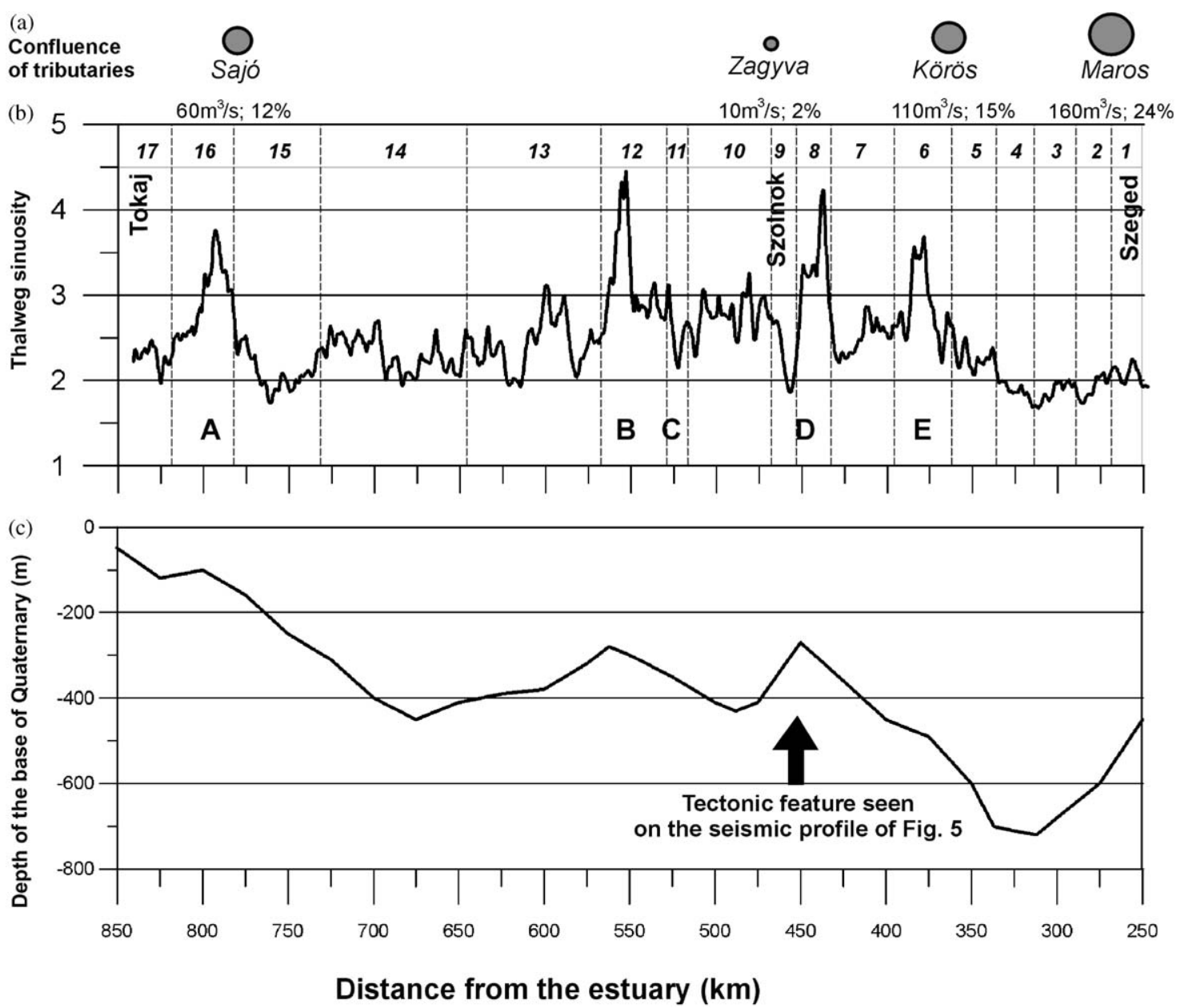

Fig. 2. Important characteristics of the Tisza River between the cities of Tokaj and Szeged (see Fig. 1). (a) Confluence of the tributaries. The size of the circles refers to the discharge of the tributary, in $\mathrm{m}^{3} / \mathrm{s}$ units under the circles. The percent data shows the discharge ratio of the tributary and the Tisza River at the confluence. (b) Thalweg sinuosity of the Tisza River. Italic numbers and vertical dashed lines indicate the subsections (see text). Capital letters show the discussed sinuosity anomalies. (c) Depth to the base of Quaternary strata (Franyó, 1992), and a zone of tectonic deformation derived from the seismic data of Tóth et al. (1997).

Riverine seismic surveys were taken in 1997 along the major part of the Tisza River, between the cities of Tokaj and Szeged. This was selected as a study section for river planform analysis. It is located between 250 and $840 \mathrm{~km}$ from the estuary, measured along the longer, pre-regulation channel. As there is only minor variance of the valley slope along the study section, the river planform is primarily controlled by the water and sediment discharge of the tributaries. Fortunately, a long part of the study section is free of major confluences (Fig. 2a) which offers excellent conditions for the analysis.

The goal of this study is to find a correlation between the known geological features (e.g. subsidence centres, and other seismically detected deformation features) and river planform changes and to show the applicability of river pattern analysis for neotectonic studies.

\section{Method and results}

As the study section of the Tisza River has been meandering throughout the entire Holocene, the morphometric parameters of meandering rivers can be used for planform analysis. For numerical and quantitative approaches, Schumm (1963) suggested to define the sinuosity of a section of a meandering river as a ratio of the channel length and the geometrical distance between its endpoints. The dependence of the channel sinuosity on the slope angle was studied by Schumm and Khan (1972) using flume experiments. Setting a given discharge with constant sediment load, and increasing the slope of the flume the flow was straight at low slope values and when a critical dip was reached, it started meandering. The sinuosity of the thalweg increased with increasing slope to a point where it was maximum, beyond this maximum the sinuosity quickly fell and the 
mechanism of braiding started. This behaviour of the sinuosity as a slope variance indicator, is the starting point of tectonic studies based on river analyses (e.g. Miall, 1996; Pinter, 1996).

Ouchi (1985) showed, also by flume model experiments, that a meandering flow crossing a region of uplift changes its sinuosity. Naturally, the sinuosity decreases upstream of the uplift axis and increases downstram. This model result was verified in studies of North American rivers (Adams, 1980; Burnett and Schumm, 1983; Marple and Talwani, 1993, 2000).

The present course of the Tisza River is a result of drastic river regulation and flood control works carried out between 1846 and 1910. Its total length was reduced about to the $60 \%$ of the original one, while the channel slope increased from around 4 to $6.5 \mathrm{~cm} / \mathrm{km}$ at the study section (Lászlóffy, 1982). The sinuosity of the presentday channel is far from the original. For the planform analysis, the sinuosity data of the original, pre-regulation channel has been derived from the reconstructed river course. Therefore, topographic map sheets in a scale of 1:28.800 of the 2nd military survey of the Austro-Hungarian Empire (produced by the Institute of Military Geography, Vienna; reprints are available at the Hungarian Archive of Military History, Budapest) were used to reconstruct the last undisturbed river course. These sheets were surveyed between 1850 and 1863, using the Cassini-Soldner projection and the Vienna1806 datum. The maps were fitted to the Hungarian national grid and the HD72 datum by rectification, using the ER Mapper ${ }^{\circledR}$ GIS software (for details of the mentioned geodetical and cartographical references, see Mugnier, 1999). The transformation error was below $40 \mathrm{~m}$ and not a systematic one. The centreline of the channel was digitized manually, and, subsequently, the distance of the vertices was set to $250 \mathrm{~m}$ along the river thalweg.

The sinuosity was computed in two different ways:

1. For each vertice of the digitized river course a $50 \mathrm{~km}$ long section ('window') was assigned from $25 \mathrm{~km}$ (100 vertices) upstream of it to the same distance downstream, along the course. Getting the Cartesian distance $(D)$ between the endpoints of this selected section, the sinuosity $(S)$ at the given vertex, with a window-size of $W$ (here $W=50 \mathrm{~km}$ ) is:

$S=\frac{W}{D}$.

The resulted thalweg sinuosity of the study section of the Tisza River is shown in Fig. 2b. As this function is too detailed for showing on a map, the sinuosity was computed also by another, more simple way.

2. Seventeen subsections of the study section of the river were selected based on the morphometry of individual meander curves by Mike (1991). The sinuosity of each subsection was calculated by dividing the

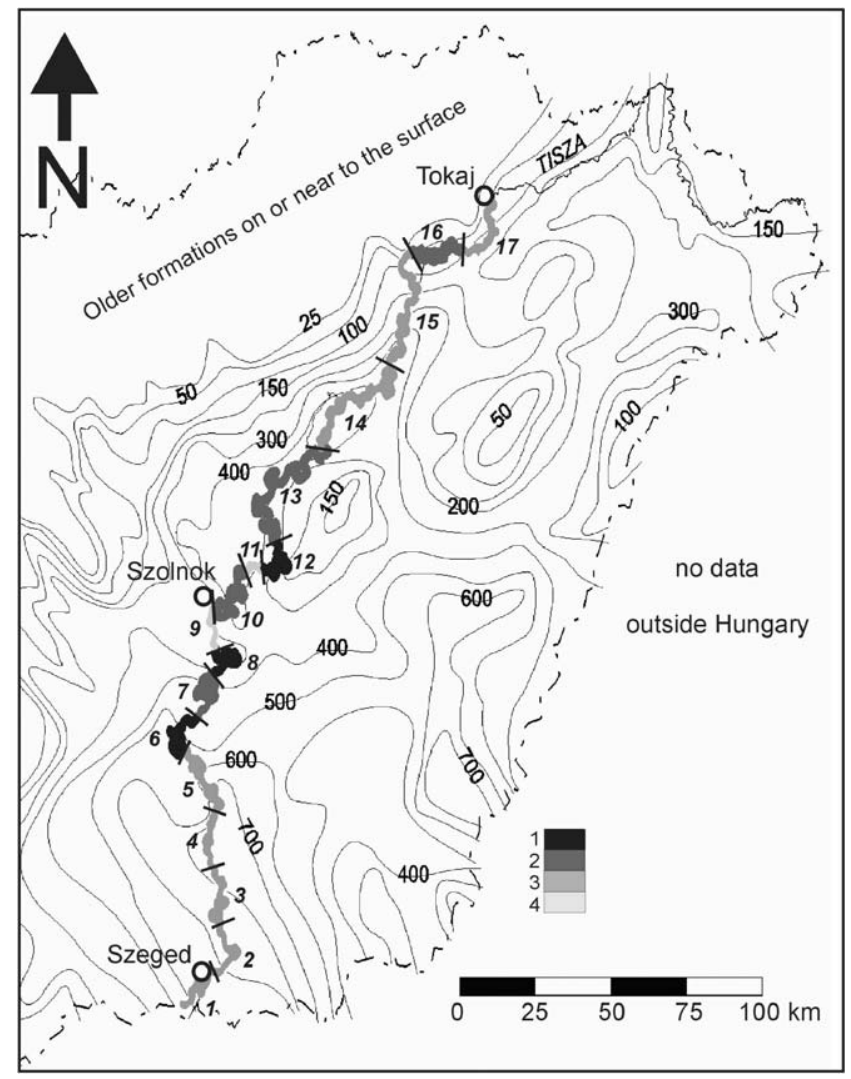

Fig. 3. Subsections and sinuosity of the Tisza River prior to the river regulations (at about 1840). Different grey shadings indicate the average thalweg sinuosity of the subsections (see text) as follows: $1=$ high sinuosity (above 3 ); $2=$ intermediate sinuosity (2.5-3); $3=$ normal sinuosity (1.5-2.5); $4=$ low sinuosity (below 1.5 ). Contour lines with numbers show the thickness of the Quaternary strata (Franyó, 1992) in meters. Small numbers along the river refer to the subsections.

thalweg length of the given section by the Cartesian distance between the endpoints of it (Fig. 3). Note that the sinuosity computed this way can differ remarkably from the results of the first method only in the case of a subsection shorter than the used window-size of $50 \mathrm{~km}$.

Along with the sinuosity, the thickness of the Quaternary sediments (Franyó, 1992) is shown in Fig. 2c, and as a map background also in Fig. 3. Concerning the reliability of this data set it has to be underlined, that the definition of the Pliocene-Quaternary boundary in terrestrial environments is still a matter of debate (Partridge, 1997). However, the main pattern of the Quaternary thickness map in the Great Hungarian Plain is quite reliable because good magnetostratigraphic constraints are available (Rónai, 1985). Recent vertical movement data derived from repeated precise levellings (Joó, 1992) was considered but not used because it shows severe human impact due to compac- 


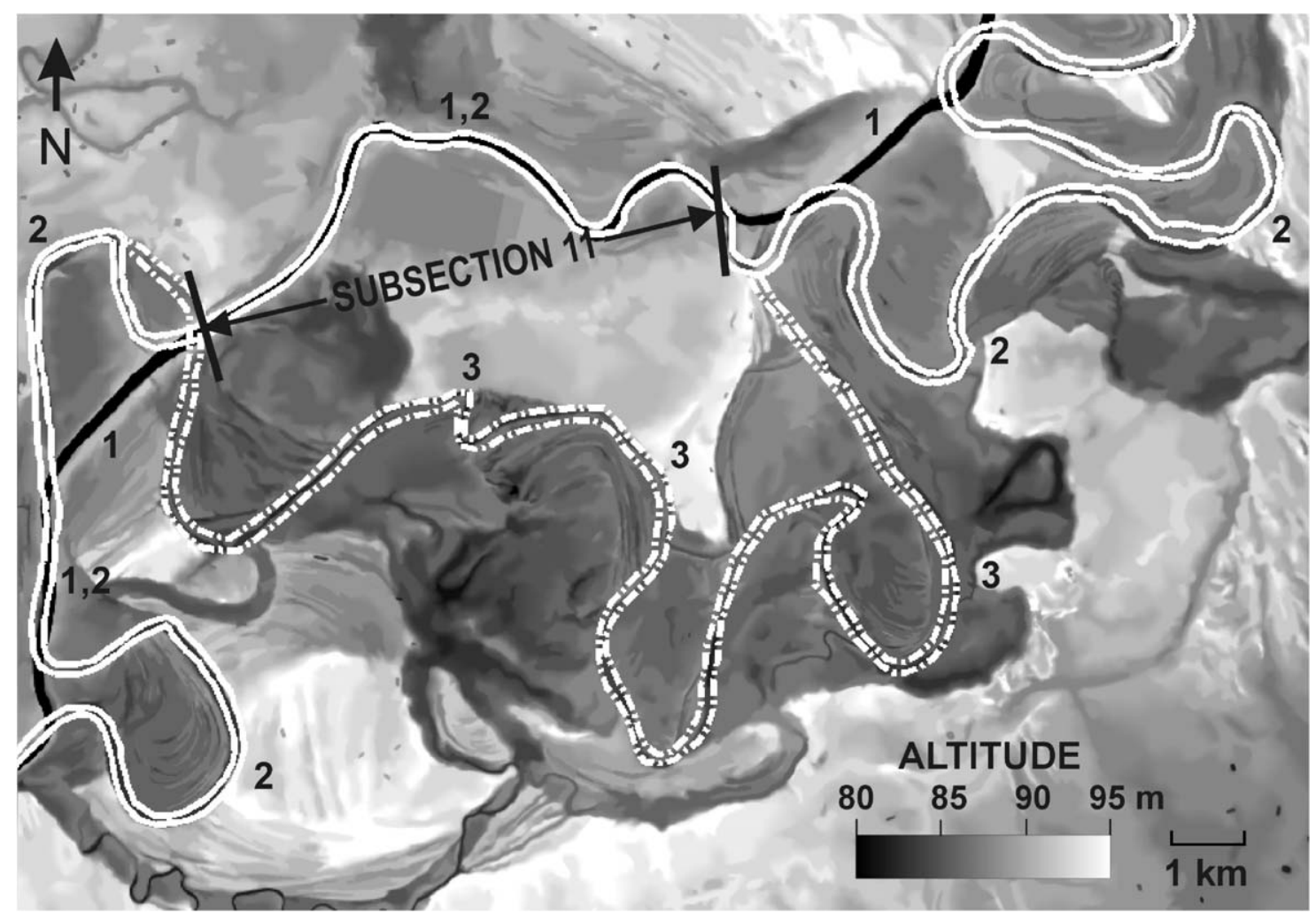

Fig. 4. Courses of the Tisza River around the subsection 11, plotted on a digital elevation model (derived from 1:10,000 scale topographic maps of Hungary). Numbers indicate the following river courses: $1=$ present, regulated channel (black); $2=$ the last natural channel just before the river regulation (continuous white); $3=$ a paleochannel (dash-dotted white), of about $5 \mathrm{kyr}$ ago. Note the remarkable change of sinuosity between the paleochannel (3) and the last natural channel (2).

tion induced by fluid extraction from the beginning of the 20th century (Timár and Rácz, 2002).

\section{Discussion}

According to the results of Ouchi (1985), high to low and low to high sinuosity changes indicate that the river crosses subsidence or uplift axes, respectively. In case of an area subsiding as a whole like the GHP, the terms 'subsidence' and 'uplift' mean not absolute vertical movements but differential displacements relative to the upstream and downstream sections of the rivers.

In the study section of the Tisza River the most evident sinuosity changes are as follows (Fig. 2b):

(A) The rise and fall of the sinuosity in the subsection 16 , at 805 and $775 \mathrm{~km}$, respectively.

(B) The rise and fall of the sinuosity in the subsection 12 , at 560 and $545 \mathrm{~km}$, respectively.

(C) The fall of sinuosity in the subsection 11 at $525 \mathrm{~km}$.

(D) The rise and fall of the sinuosity at the two endpoints of subsection 8 at 460 and $435 \mathrm{~km}$, respectively.
(E) The high sinuosity anomaly in the subsection 6, between 395 and $360 \mathrm{~km}$.

There is a good correlation between the thickness of Quaternary sediments as a subsidence indicator and the sinuosity (see Fig. 2). The anomalies B and D follow the local minima of the Quaternary thickness (and hence, the subsidence), and even the anomalies $\mathrm{A}$ and $\mathrm{E}$ correlate with a smaller local minimum in the thickness. However, it can be seen that the fall of the sinuosity at the anomalies $\mathrm{A}$ and $\mathrm{E}$ also correlates with the confluence of the Sajó and Körös Rivers, which increases the water discharge and the sediment load at those places (Lászlóffy, 1982). Other sinuosity falls in the study section may be interpreted as consequences of the rivers self-organization to the energy balance (see Langbein and Leopold, 1966). One example can be seen in Fig. 4, which shows the subsection 11, anomaly C, where the highly sinuous mid-Holocene paleochannel has changed for an almost straight recent channel without any apparent tectonic reasons.

Concerning the results of the high-resolution riverine seismic survey (Tóth et al., 1997), the vast majority of the study sections do not exhibit any tectonic deformation. However, a clear flower structure (Fig. 5b), 


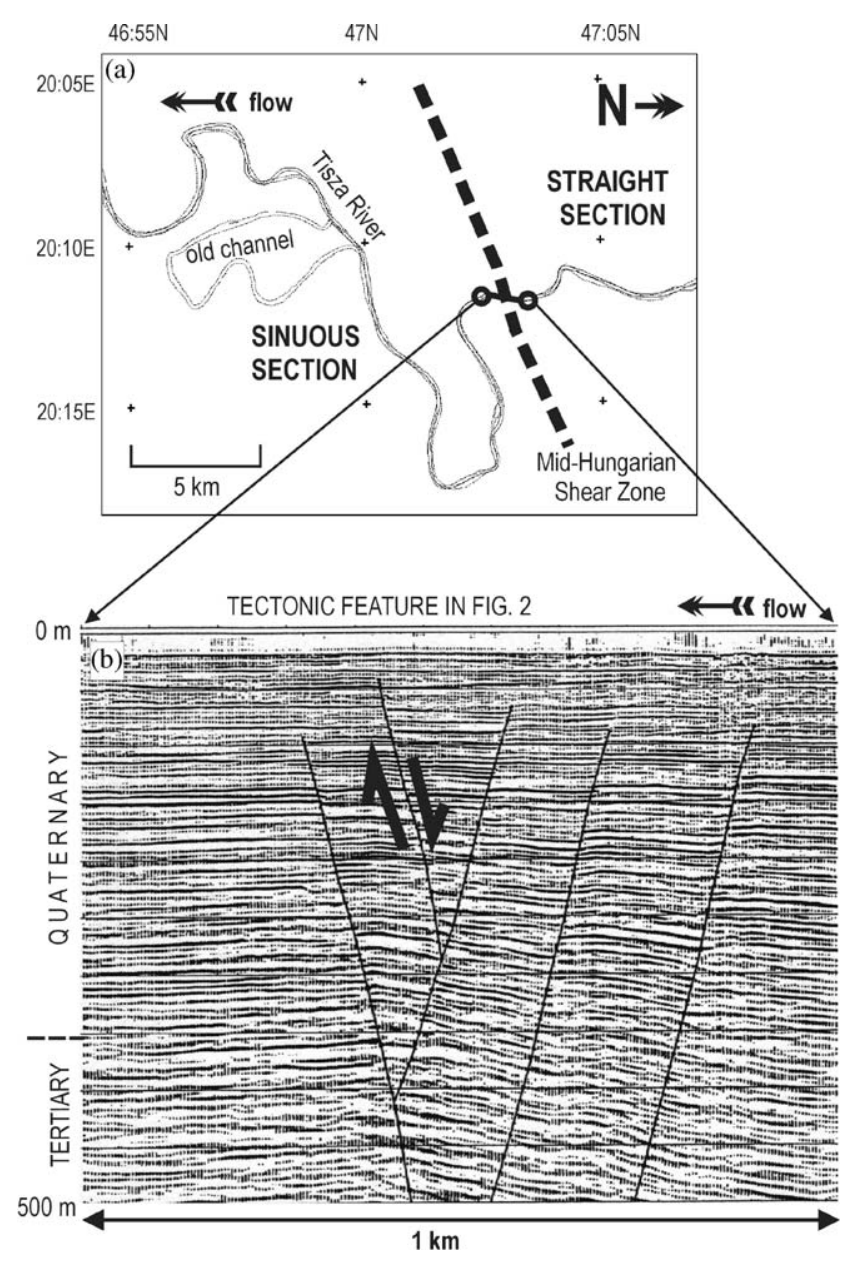

Fig. 5. Correlation of a sharp sinuosity change and a fault zone at the boundary of the subsections 8 and 9. (a) A map showing the preregulation and the present courses of the Tisza River and the location of the seismic section below. (b) The seismic section (after Tóth et al., 1997) measured on the river and showing the young wrench fault associated with the Mid-Hungarian Shear Zone.

associated with the Mid-Hungarian Shear Zone (Lörincz et al., 2002), has been imaged right at the boundary of subsections 8 and 9. This has been interpreted (Bada, 1999; Horváth and Bada, 2001) as a sinistral strike-slip fault with a small normal faulting component. This feature correlates with the most dramatic planform change along the study section: the rising sinuosity at anomaly $\mathrm{D}$, exactly at the border of subsections 8 and 9. Moreover, the normal faulting component of the fault explains well the zone of larger Quaternary thickness and therefore the higher subsidence and the direction of the sinuosity change as well. This is a clear evidence of the ongoing tectonic activity of the Mid-Hungarian Shear Zone.

\section{Interpretation in terms of river dynamics}

According to the flume model results of Schumm and Khan (1972), at a given discharge the sinuosity of meandering rivers increases with the valley slope only to a critical dip. If the slope further increases then the meandering river starts to straighten. It is obvious that our analysis is valid only in the slope interval below this critical value. The specific question emerges where this critical dip value is located along the Tisza River. It will be seen that in our attempt to answering this specific question we arrive at a more general result on the controlling factors of river planform changes.

Let us use the original graph of Schumm and Khan (1972); the 'vertical' plane on Fig. 6, which gives the sinuosity vs. slope relationship, together with the discrimination lines between straight, meandering and braided patterns. The same discrimination lines were presented on the graphs of Leopold and Wolman (1957) and Ackers and Charlton (1971) in a co-ordinate system of bankfull discharge and channel slope. As the two graphs have different meanings of 'slope' (valley and channel), the one of Schumm and Khan (1972) was recalculated in order to have the channel slope as a horizontal axis. This makes it possible to combine the two graphs and arrive at a three-dimensional chart, showing the sinuosity as function of the channel slope and bankfull discharge (Fig. 6). To construct this chart, it is assumed that the relationship of Schumm and Khan (1972) is basically valid for different values of discharge, therefore similar graphs can be drawn between the two discrimination lines of Leopold and Wolman (1957) and Ackers and Charlton (1971) at any discharge (Fig. 6). This enables to project the maximum sinuosity value onto the slope vs. discharge plane, and thus define a new discrimination line (dashed line in Fig. 6).

This line divides the meandering zone into two parts: the zone of self-organizing meandering (sensu Turcotte, 1992; Stølum, 1996) and the zone of 'unorganized meandering' because here the sinuosity decreases with the increasing slope.

Plotting the slope and discharge data pairs along the alluvial section of the Tisza River, a trajectory is received (the short-dashed line in Fig. 7). It can be seen from Fig. 7 that the study section plots completely in the zone of self-organizing meandering, which means that our analysis on the tectonic influence on the channel sinuosity is justified. Furthermore, it shows that in case of the Tisza River the braided to meandering transition (sensu Leopold and Wolman, 1957) refers to the border of the true braided zone, while the classic self-organizing meandering occurs only beneath the maximum sinuosity line. The section in-between is the range of 'unorganized meandering', and interestingly enough, in the case of the Tisza River this section coincides with the zone of intermediate streams (sensu Lane, 1957) and the wandering flow pattern (sensu Miall, 1977). 


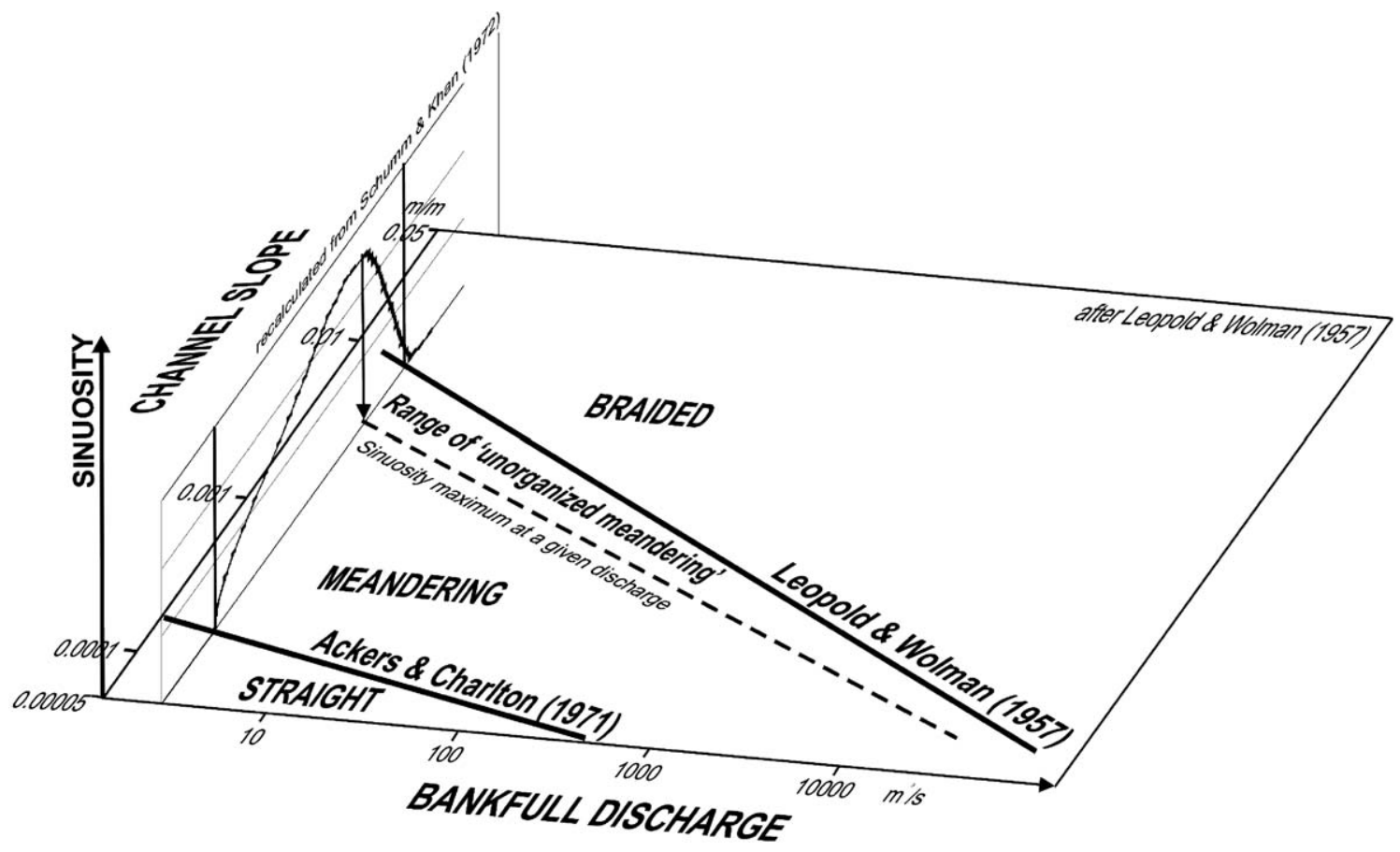

Fig. 6. Derivation of the line (dashed) showing the slope resulting the maximum sinuosity at any discharge by the combination of the channel slope vs. bankfull discharge diagram (Leopold and Wolman, 1957; Ackers and Charlton, 1971) with the chart of sinuosity vs. slope (after Schumm and Khan, 1972). The vertical axis has no units because of the qualitative approach of the combination.

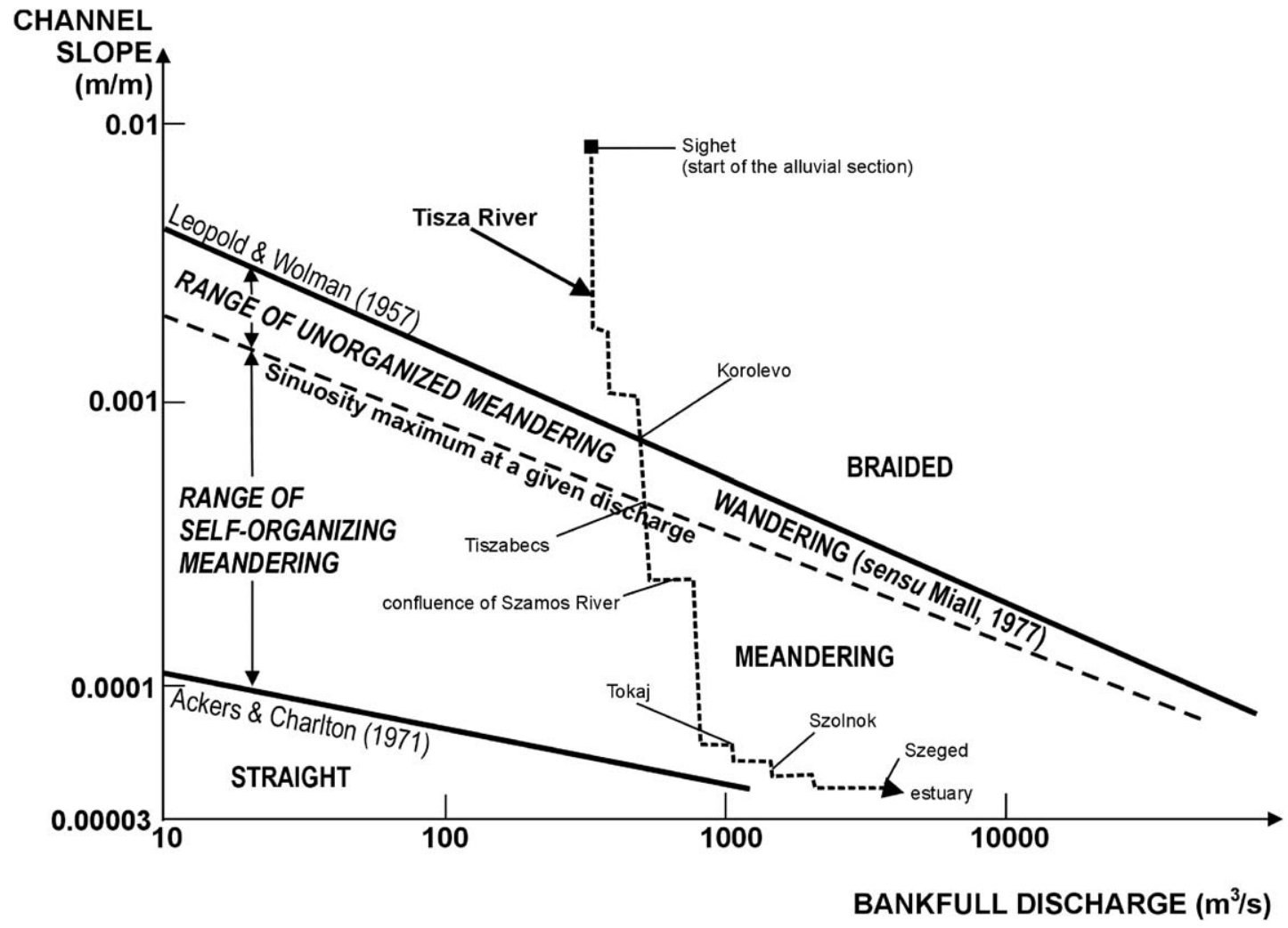

Fig. 7. Discharge vs. channel slope discrimination diagram (after Leopold and Wolman, 1957; Ackers and Charlton, 1971), and the plot of the alluvial section of the Tisza River, showing the river planform change from braided, via wandering to meandering. For the determination of the line of maximum sinuosity (dashed), see Fig. 6 (see text for discussion). 


\section{Conclusions}

The analysis of the pre-regulation planform geometry of the study section of the Tisza River shows that the sinuosity of the river is strongly correlated with the position of faults and subsidence anomalies. From a tectonic point of view this implies that the MidHungarian Shear Zone should be considered an active tectonic feature.

As a more general result, by combination of classical river dynamic charts we deduced a new discrimination line separating the so far single range of meandering into two subunits:

- the self-organizing meandering, and

- the unorganized meandering.

This latter one corresponds to conditions when the channel sinuosity decreases, albeit the channel slope increases. On the example of the Tisza, a representative alluvial river, the zone of unorganized meandering equals to the wandering river pattern of Miall (1977).

\section{Acknowledgements}

This study was carried out in the framework of a project sponsored by the Hungarian Space Office and the Ministry of Transport and Water Management (TP 094) and the Hungarian National Science Foundation (OTKA T-034979).

The digital elevation model on Fig. 4 has been created using maps whose content is owned by the Institute of Geodesy, Cartography and Remote Sensing (FÖMI) and published with its permission.

The author is grateful to Frank Horváth, his supervisor, for the help in the structural improvement of the paper and also for the final corrections in the text.

\section{References}

Ackers, P., Charlton, F.G., 1971. The slope and resistance of small meandering channels. Proceedings of the Institute of Civil Engineers Supplementary Paper 73625-5, 349-370.

Adams, J., 1980. Active tilting of the United States midcontinent: geodetic and geomorphic evidence. Geology 8, 442-446.

Bada, G., 1999. Cenozoic stress field evolution in the Pannonian Basin and surrounding orogens-Inferences from kinematic indicators and finite element modelling. Netherlands Research School of Sedimentary Geology publication no. 990101. Amsterdam, 204pp.

Bada, G., Horváth, F., Gerner, P., Fejes, I., 1999. Review of the present-day geodynamics of the Pannonian basin: progress and problems. Journal of Geodynamics 27, 501-527.

Burnett, A.W., Schumm, S.A., 1983. Alluvial river-response to neotectonic deformation in Louisiana and Mississippi. Science $222,49-50$

Csontos, L., Nagymarosi, A., Horváth, F., Kovač, M., 1992. Tertiary evolution of the Intra-Carpathian area: a model. In: Ziegler, P. A.
(Ed.), Geodynamics of Rifting. Vol. 1. Case History Studies on Rifts: Europe and Asia. Tectonophysics 208, 221-241.

Franyó, F., 1992. Thickness of Quaternary sediments in Hungary. Map, Scale: 1:500000. Hungarian Geological Institute, Budapest.

Gábris, Gy., 1987. Correlation between meander properties and Holocene discharges in the Great Hungarian Plain. In: Gardiner V. (Ed.), International Geomorphology Conference 1985, Part I. Wiley, Chichester, pp. 723-730.

Gábris, Gy., 1998. Late glacial and post glacial development of drainage network and the paleohydrology in the Great Hungarian Plain. In: Bassa, L., Kertész, Á. (Eds.), Windows on Hungarian Geography. FKI, Budapest, pp. 23-36.

GLOBE Task Team \& others (Hastings, D.A., Dunbar, P.K., Elphingstone, G.M., Bootz, M., Murakami, H., Maruyama, H., Masaharu, H., Holland, P., Payne, J., Bryant, N.A., Logan, T.L., Muller, J.-P., Schreier, G., MacDonald, J.S. (Eds.), 1999. The Global Land One-kilometer Base Elevation (GLOBE) Digital Elevation Model, Version 1.0. National Oceanic and Atmospheric Administration, National Geophysical Data Center, Boulder, CO. Digital database on the World Wide Web. (URL: http:// www.ngdc.noaa.gov/seg/topo/globe.shtml).

Horváth, F., 1993. Towards a mechanical model for the formation of the Pannonian Basin. Tectonophysics 226, 333-357.

Horváth, F., Bada, G., 2001. Active tectonics in the Pannonian Basin: an overview of structural styles. EGS 3rd Stephan Müller Topical Conference, Abstract book p. 25, 22-26 September, 2001. Balatonfüred, Hungary.

Horváth, F., Cloetingh, S., 1996, Stress-induced late-stage subsidence anomalies in the Pannonian basin. In: Cloetingh, S., Ben Avraham, Z., Sassi, W., Horváth, F. (Eds.), Dynamics of extensional basins and inversion tectonics. Tectonophysics 266, 287-300.

Joó, I., 1992. Recent vertical surface movements in the Carpathian Basin. Tectonophysics 202, 129-134.

Kázmér, M., 1990. Birth, life and death of the Pannonian Lake. Palaeogeography, Palaeoclimatology, Palaeoecology 79, 171-188.

Lane, E.W., 1957. A study of the shape of channels formed by natural streams flowing in erodible material. US Army Corps Eng., Missouri River Div., Omaha, NE, Sediment Series 9, 106pp.

Langbein, W.B., Leopold, L.B., 1966. River meanders: theory of minimum variance. USGS Professional Paper 422H, 1-15.

Lászlóffy, W., 1982. The Tisza River-Waterworks and Water Management in the Tisza Drainage System (in Hungarian) Akadémiai Kiadó, Budapest, 610pp.

Leopold, L.B., Wolman, M.G., 1957. River channel patterns; braided, meandering and straight. USGS Professional Paper 282B, 1-73.

Lőrincz, D.K., Horváth, F., Detzky, G., 2002. Neotectonics and its relation to the Mid-Hungarian Mobile Belt. In: Cloetingh, S., Horváth, F., Bada, G., Lankreijer, A. (Eds.), Neotectonics and Seismicity of the Pannonian Basin and Surrounding Orogens-A memoir on the Pannonian Basin. EGU Stephan Mueller Special Publication Series 3, 247-266.

Marple, R.T., Talwani, P., 1993. Evidence of possible tectonic upwarping along the South Carolina coastal plain from an examination of river morphology and elevation data. Geology 21, 651-654.

Marple, R.T., Talwani, P., 2000. Evidence for a buried fault system in the Coastal Plain of the Carolinas and Virginia - implications for neotectonics in the southeastern United States. Geological Society of America Bulletin 112, 200-220.

Miall, A.D., 1977. A review of the braided river depositional environment. Earth Science Review 13, 1-62.

Miall, A.D., 1996. The Geology of Fluvial Deposits. Springer, Berlin, 522pp.

Mike, K., 1975. Utilization of the analysis of ancient river beds for the detection of Holocene crustal movements. Tectonophysics 29 , 359-368. 
Mike, K., 1991. Paleohydrology and Surface Water History of Hungary (in Hungarian). Aqua, Budapest, 698pp.

Mugnier, C.J., 1999. Grids \& datums-Republic of Hungary. Photogrammetric Engineering and Remote Sensing 65, 423 and 425.

Ouchi, S., 1985. Response of alluvial rivers to slow active tectonic movement. Geological Society of America Bulletin 96, 504-515.

Partridge, T.C. (Ed.), 1997. The Plio-Pleistocene boundary. Quaternary International 40, 100.

Pinter, N.C., 1996. Active Tectonics. Prentice-Hall, Upper Saddle River, NJ, 338pp.

Pogácsás, Gy., Lakatos, L., Barvitz, A., Vakarcs, G., Farkas, Cs., 1989. Pliocene-Quaternary strike-slip faults in the Great Hungarian Plain (in Hungarian). Általános Földtani Szemle 24, 149-169.

Rónai, A., 1985. Quaternary geology of the Great Hungarian Plain (in Hungarian with English summary). Geologica Hungarica, Series Geologica 21, 3-446.

Schumm, S.A., 1963. A tentative classification of alluvial river channels. US Geological Survey Circular V477.

Schumm, S.A., Khan, H.R., 1972. Experimental study of channel patterns. Geological Society of America Bulletin 83, 1755-1770.
Schumm, S.A., Dumont, J.F., Holbrook, J.M., 2000. Active Tectonics and Alluvial Rivers. Cambridge University Press, Cambridge (Chapter 7: Lateral Response; Pannonian Basin, Hungary, pp. 175-178).

Stølum, H.H., 1996. River meandering as a self-organization process. Science 271, 1710-1713.

Timár, G., Rácz, T., 2002. The effects of neotectonic and hydrological processes on the flood hazard of the Tisza region (E. Hungary). In: Cloetingh, S., Horváth, F., Bada, G., Lankreijer, A. (Eds.), Neotectonics and Seismicity of the Pannonian Basin and Surrounding Orogens - A Memoir on the Pannonian Basin. EGU Stephan Mueller Special Publication Series 3, 267-275.

Tóth, L., Mónus, P., Zsíros, T., Kiszely, M., Kosztyu, Z., Wéber, Z., 1995. Hungarian Earthquake Bulletin. GeoRisk, Budapest.

Tóth, T., Vida, R., Horváth, F., Simpkin, P., 1997. Shallow-water single and multichannel seismic profiling in a riverine environment. The Leading Edge 16, 1691-1695.

Turcotte, D.L., 1992. Fractals and Chaos in Geology and Geophysics. Cambridge University Press, Cambridge, 398pp.

Vandenberghe, J., 1995. Timescales, climate and river development. Quaternary Science Reviews 14, 631-638. 